\title{
PENGARUH INTERPERSONAL INFLUENCE, ALTRUISM, DAN ENVIRONMENT KNOWLEDGE TERHADAP GREEN PURCHASING BEHAVIOUR KONSUMEN THE BODY SHOP YANG DIMEDIASI OLEH ENVIRONMENT ATTITUDE
}

\author{
Yokie Radnan Kristiyono ${ }^{1}$ \\ Universitas Pelita Harapan \\ paulus.radnan@uph.edu \\ Caroline Felim ${ }^{2}$ \\ Universitas Pelita Harapan \\ carolinefelim@yahoo.com \\ Diterima 9 Januari 2021 \\ Disetujui 23 Mei 2021
}

\begin{abstract}
This research was conducted to determine the relationship between interpersonal influence, altruism, environmental knowledge and green purchasing behaviour mediated by environmental attitudes towards consumers of The Body Shop in the Jakarta, Tangerang, Depok, Bekasi and Bogor areas. This research will focus on consumers of The Body Shop where the researchers conducted this research because the awareness of young consumers towards environmentally friendly products is still low. This research was conducted using a quantitative approach. The data used in this study were collected through an instrument in the form of an electronic questionnaire, namely Google Form that was spread on social media. The findings of this research show that interpersonal influence has a positive and significant effect on environment attitude; altruism has a positive effect on environment attitude; environment knowledge has no positive effect on environment attitude; and environment attitude has a positive effect on green purchasing behaviour. The managerial implication that can be given from this research is that marketers can increase consumer knowledge of the environment so that it can encourage consumers to pay attention to their attitudes towards the environment and can lead to consumer buying behaviour for environmentally friendly products.
\end{abstract}

Keywords: Interpersonal Influence; Altruism; Environment Knowledge; Green Purchasing Behavior; Environment Attitude

\section{PENDAHULUAN}

\subsection{Latar Belakang}

Pada abad kedua puluh satu ini, dunia dihadapi oleh tantangan lingkungan seperti konservasi sumber daya, perubahan iklim dan pemanasan global. Dimana, hal itu berkaitan erat dengan praktik bisnis yang berdampak pada ekonomi, lingkungan dan masyarakat (Kumar et al., 2012). Dalam industri komestik saat ini mulai dikenalkan penggunaan bahan alami dalam proses pengolahan produk kosmetik. Adapun alasan peningkatan popularitas penggunaan bahan alami pada kosmetik adalah efek negatif dari bahan sintetis terhadap kesehatan dan lingkungan (Jennifer Gubitosa, Vito Rizzi, Paola Fini, 2019). Salah satu merek kosmetik yang melakukan strategi pemasaran green marketing adalah The Body Shop yang sudah melakukan 
kampanye-kampanye mereka yang ramah lingkungan. Salah satu kampanye yang dilakukan oleh The Body Shop adalah forever against animal testing. The Body Shop bekerja sama dengan influencer untuk melakukan kampanye ini yang bertujuan untuk mendorong kegiatan sosial dan mendrong penjualan produk mereka.

Berdasarkan laporan penjualan perawatan kulit di Indonesia oleh Euromonitor International pada juni 2020 melaporkan bahwa masyarakat Indonesia menjadi semakin fokus pada kesehatan dan perawatan kulit dalam beberapa tahun terakhir. Dengan adanya fenomena ini, timbul dampak pada industri kosmetik terutama pada bidang kecantikan dan perawatan pribadi pada tahun 2019. Produk perawatan kulit meningkat pada tahun 2019, dengan perempuan lebih memilih produk natural dan laki-laki lebih memilih merek terpercaya (International, 2020). Menjadi negara yang memiliki ekonomi terbesar di Asia Tenggara, Indonesia telah menikmati pertumbuhan ekonomi yang sehat dan stabil selama bertahun-tahun. Indonesia sekarang menjadi rumah bagi kelompok konsumen yang semakin canggih yang memperhatikan penampilan dan kesejahteraan mereka (Wibowo, 2020). Pada tahun 2019, pendapatan e-commerce di Indonesia mencapai US \$ 18,7 miliar. Pada riset yang dilakukan oleh McKinsey memperkirakan bahwa angka ini akan terus bertumbuh hingga US \$ 40 miliar pada tahun 2022 (Wibowo, 2020).

Bedasarkan laporan Euromonitor pada tahun 2019 sebelum penyebaran COVID-19, Penjualan produk perawatan kulit sekarang diharapkan tumbuh sebesar 9\% pada tahun 2020 . Ini sebanding dengan perkiraan kenaikan $8 \%$ yang diharapkan untuk tahun 2020. Sebagian besar area produk perawatan kulit diperkirakan akan mengalami pertumbuhan nilai yang lebih kuat dengan harga konstan pada tahun 2020 akibat dari dampak pandemi COVID-19. Banyak konsumen memilih untuk mencuci tangan lebih sering dengan harapan dapat mencegah penularan virus, seringkali setiap kali mereka kembali ke rumah, dengan ini meningkatkan penggunaan perawatan kulit pasca-pencucian termasuk perawatan tubuh dan pelembab dan perawatan serta mendukung pertumbuhan penjualan yang lebih kuat untuk pembersih wajah (International, 2020). Saat ini, masyarakat Indonesia semakin memperhatikan kebersihan dan penampilan mereka sehingga kosmetik dan juga barang-barang perawatan sudah menjadi bagian dari gaya hidup masyarakat Indonesia. Beberapa alasannya termasuk kesadaraan akan kebersihan, tingkat pendapatan dan pengaruh dari budaya yang populer. Sebagai pasar terbesar di Asia Tenggara dengan penduduk terbesar keempat di dunia, industri kosmetik menjadi sektor yang menarik bagi investor dalam dan luar negeri. Riset terbaru yang dilakukan oleh L'Oréal menunjukkan bahwa 75\% wanita di Indonesia lebih menyukai produk kecantikan berbahan alami (Spencer, 2018).

Sustainability pada bisnis umumnya membahas dua kategori utama yaitu : Efek bisnis terhadap lingkungan dan Efek bisnis terhadap masyarakat (Spiliakos, 2018). Sustainabiliy pada bisnis dapat dijelaskan sebagai proses pengelolaan organisasi dengan mempertimbangan tiga aspek yang berbeda, yaitu : ekonomi, sosial dan lingkungan. Ini juga dapat disebut sebagai Triple Bottom Line (Bose \& Mahajan, 2018). Menurut Donald Fuller (1999), Sustainable Marketing or Green Marketing adalah proses perencanaan, implementasi dan pengendalian pengembangan, promosi, penetapan harga, distribusi produk agar memuaskan tiga kriteria: memuaskan kebutuhan konsumen, pencapaian tujuan bisnis dan kompatibel dengan ekosistem. Perusahaan harus dapat mengaplikasikan konsep keberlanjutan pada bisnisnya, karena keberlanjutan bukan lagi menjadi suatu pilihan bagi perusahaan melainkan telah menjadi suatu kebutuhan bagi perusahaan (Kumar et al., 2012). Dengan konsep keberlanjutan inilah perusahaan dapat mencapai keunggulan kompetitif. Ini pada dasarnya telah menjadi suatu persyaratan dalam bisnis karena konsep pemasaran tidak hanya sebatas pada kebutuhan intra- 
personal dan antar-personal; hal itu diperluas untuk kebutuhan generasi mendatang (van Dam \& Apeldoorn, 1996).

Green marketing telah menjadi fokus bagi perusahaan dan masyarakat untuk saat ini (Arseculeratne \& Yazdanifard, 2013). Green marketing menjadi populer karena banyak orang yang sadar akan kerusakan yang terjadi pada lingkungan dan memilih untuk lebih peduli terhadap masalah lingkungan. Green marketing mirip dengan pemasaran tradisional, namun pada konsep green marketing menggabungkan beberapa aktivitas pemasaran yang memerlukan diferensiasi, produksi, penetapan harga, dan promosi barang atau jasa yang aman bagi lingkungan dan mampu memenuhi kebutuhan lingkungan konsumen (Taherdoost, 2018). Jenis pemasaran ini bisa jadi lebih mahal daripada bentuk pemasaran lain, tetapi juga menguntungkan karena meningkatnya permintaan. Tujuan dari green marketing adalah untuk menjual produk yang ramah terhadap lingkungan, sekaligus secara aktif mendorong konsumen dalam mendukung dan melindungi lingkungan (Stern \& Ander, 2012). Konsumen yang memiliki nilai altruisme yang tinggi cenderung memiliki sikap lingkungan yang positif (Albayrak et al., 2011). Dimana hal ini mendorong konsumen untuk membeli produk-produk yang ramah lingkungan karena mereka peduli terhadap keadaan lingkungan. Altruisme juga berperan erat dengan citra merek Gilg et al. (2005) mengidentifikasi berbagai jenis nilai-nilai dan gaya hidup yang ramah lingkungan. Dalam penelitian mereka menemukan bahwa orang yang menunjukkan perilaku ramah lingkungan dan yang kurang menunjukkan perilaku ramah lingkungan memiliki nilai yang berbeda secara signifikan. Mereka juga menemukan bahwa altruisme berperan penting sebagai salah satu pendorong dalam perilaku dan segmentasi hijau. Selain itu, demografi dianggap sebagai penentu perilaku ramah lingkungan.

Perusahaan The Body Shop terkenal dengan produk ramah lingkungannya. Tetapi, pada penelitian yang dilakukan oleh Rakhmawati (2019), dalam penelitiannya yang berjudul pengaruh green product, green brand dan green advertising terhadap keputusan pembelian produk The Body Shop di Kota Yogyakarta, disebutkan bahwa Green Product tidak berdampak positif dan signifikan terhadap keputusan pembelian konsumen The Body Shop dikarenakan objek penelitian yang digunakan adalah produk kosmetik yang ramah lingkungan. Produk kosmetik sendiri tidak memiliki manfaat secara langsung dalam waktu jangka pendek karena produk kosmetik sendiri tidak dapat memberikan perbedaan dengan jelas dalam waktu pendek. Selain itu, konsumen juga lebih cenderung untuk memperhatikan merek produk daripada produk ramah lingkungan itu sendiri. Sehingga penelitian ini dilakukan dengan tujuan untuk mengetahui perilaku pembelian produk ramah lingkungan khususnya konsumen The Body Shop yang berdomisili di Jakarta, Tangerang, Depok, Bekasi dan Bogor.

\subsection{Latar Belakang}

\section{Green Marketing}

Menurut Polonsky (2017), Pemasaran Hijau atau Lingkungan terdiri dari semua kegiatan yang dirancang untuk menghasilkan dan memfasilitasi setiap pertukaran yang ada untuk memenuhi kebutuhan dan keinginan manusia, sehingga kepuasaan dari kebutuhan dan keinginan ini terpenuhi, dampak kerusakan lingkungan yang lebih kecil. Menurut studi dari Jermier \& Prakash (2002), Green Marketing mengacu pada strategi untuk mempromosikan produk dengan menerapkan klaim lingkungan baik tentang atribut mereka atau tentang sistem, kebijakan dan proses perusahaan yang memproduksi atau menjualnya. Green marketing adalah sebuah alat untuk melindungi lingkungan meskipun tidak mudah untuk diadopsi dalam jangka pendek tetapi dalam jangka panjang akan berdampak positif bagi perusahaan. 
2. Interpersonal Influence

Interpersonal influence adalah tekanan sosial yang secara langusng diberikan kepada seseorang atau kelompok oleh orang lain atau kelompok lain dalam bentuk tuntutan, ancaman, janji imbalan atau persetujuan sosial (Pam, 2013). Pengaruh interpersonal adalah salah satu bentuk tekanan sosial. Dimana tekanan sosial diberikan kepada seseorang atau suatu kelompok melalui argumen rasional, persuasi, tuntutan dan kesesuaian (Pam, 2013).

3. Altruism

Menurut Teng et al. (2015), perasaan individu mengenai apa yang benar dan etis untuk dilakukan terdiri dari norma-norma pribadi yang termasuk dalam komitmen yang sengaja dirasakan individu dalam membuat pilihan terbaik, terlepas dari apa yang dipikirkan orang lain. Nilai altruistik termasuk demonstrasi untuk mencapai sesuatu yang baik untuk orang lain tanpa mengantisipasi akibatnya (Teng et al., 2015). Suatu perilaku dapat dideskripsikan sebagai altruistik jika dimotivasi oleh keinginan untuk menguntungkan orang lain selain diri sendiri.

4. Environment Knowledge

Environment knowledge mengacu pada pemahaman seseorang tentang hal-hal dan objek pada lingkungan (Lee, 2011). Bedasarkan penelitian Chang (2011), elemen yang membentuk evaluasi environmental knowledge dapat diklasifikasikan menjadi tiga bagian yaitu: ecology, environmetal science, dan environmental issue.

- Ecology merupakan konservasi lingkungan dan keanekaragaman makhluk hidup.

- Environmental science membahas tentang pencemaran dan pencegahan polusi udara, air, tanah, suara dan limbah atau sampah yang dihasilkan oleh manusia sanitasi lingkungan dan kebersihan makanan, dan energi yang berkelanjutan.

- Environmental issue membahas tentang masalah yang terjadi pada lingkungan seperti, kebersihan penduduk, pelestarian sumber daya air dan pencegahan pencemaran air, serta pencemaran sampah dan limbah bisnis.

\section{Environment Attitude}

Menurut studi dari Mathew (2012) mengemukakan bahwa environment attitude menunjukkan kombinasi keyakinan terhadap orang atau benda yang berhubungan langsung dengan lingkungan, kondisi khusus lingkungan, dan seluruh lingkungan. Ketika seseorang memiliki emosi ini, maka orang tersebut akan berpartisipasi aktif dalam perlindungan lingkungan, membangkitkan rasa kepedulian yang kuat terhadap lingkungan, dan meningkatkan motivasi untuk berkembang (Mitchener \& Jackson, 2012). Menurut Gohary et al. (2013), environmental attitude merupakan tingkat pengabdian dan dukungan seseorang terhadap lingkungan. Environmental attitude dapat dibatasi sebagai karakteristik individu yang terbentuk dalam jangka panjang. Mereka akan terus peduli dengan masalah lingkungan dan pada akhirnya mengambil tindakan dalam perlindungan lingkungan.

\section{Green Purchasing Behaviour}

Perilaku konsumen untuk pembelian produk ramah lingkungan umumnya dievaluasi dalam hal kesediaan atau niat konsumen untuk membeli produk ramah lingkungan dan perilaku atau niat yang sadar pada akhirnya berubah menjadi keputusan untuk membeli (Joshi \& Rahman, 2015). Theory of Planned Behaviour (TPB) sangat berguna dalam memprediksi niat dan perilaku konsumen dalam berbagai bidang (Mathieson, 1991). Menurut Ajzen (1985) Theory of Planned Behaviour (TPB) menyebutkan terdapat tiga faktor dalam membentuk niat perlilaku seseorang, yaitu: 
a. Attitude toward the behaviour, mengacu pada sejauh mana seseorang dapat menilai atau mengevaluasi jika suatu perilaku menguntungkan atau tidak menguntungkan.

b. Subjective norm, merupakan persepsi sosial yang mempengaruhi atau mendesak seseorang untuk melakukan atau sebaliknya tidak melakukan sesuatu.

c. Percieved behaviour control, mengacu pada kemudahan atau kesulitan yang dirasakan seseorang untuk melakukan sesuatu. Orang-orang yang memiliki tingkat kendali yang lebih tinggi, lebih cenderung memiliki niat yang kuat untuk melakukan suatu perilaku tertentu.

\subsection{Kerangka Penelitian}

Model penelitian yang akan digunakan merupakan usulan model penelitian replikasi dari penelitian oleh Uddin \& Khan (2018). Model penelitian ini menjelaskan mengenai hubungan antara interpersonal influence, altruism, environmental knowledge terhadap green purchasing behaviour yang dimediasi oleh environmental attitude.

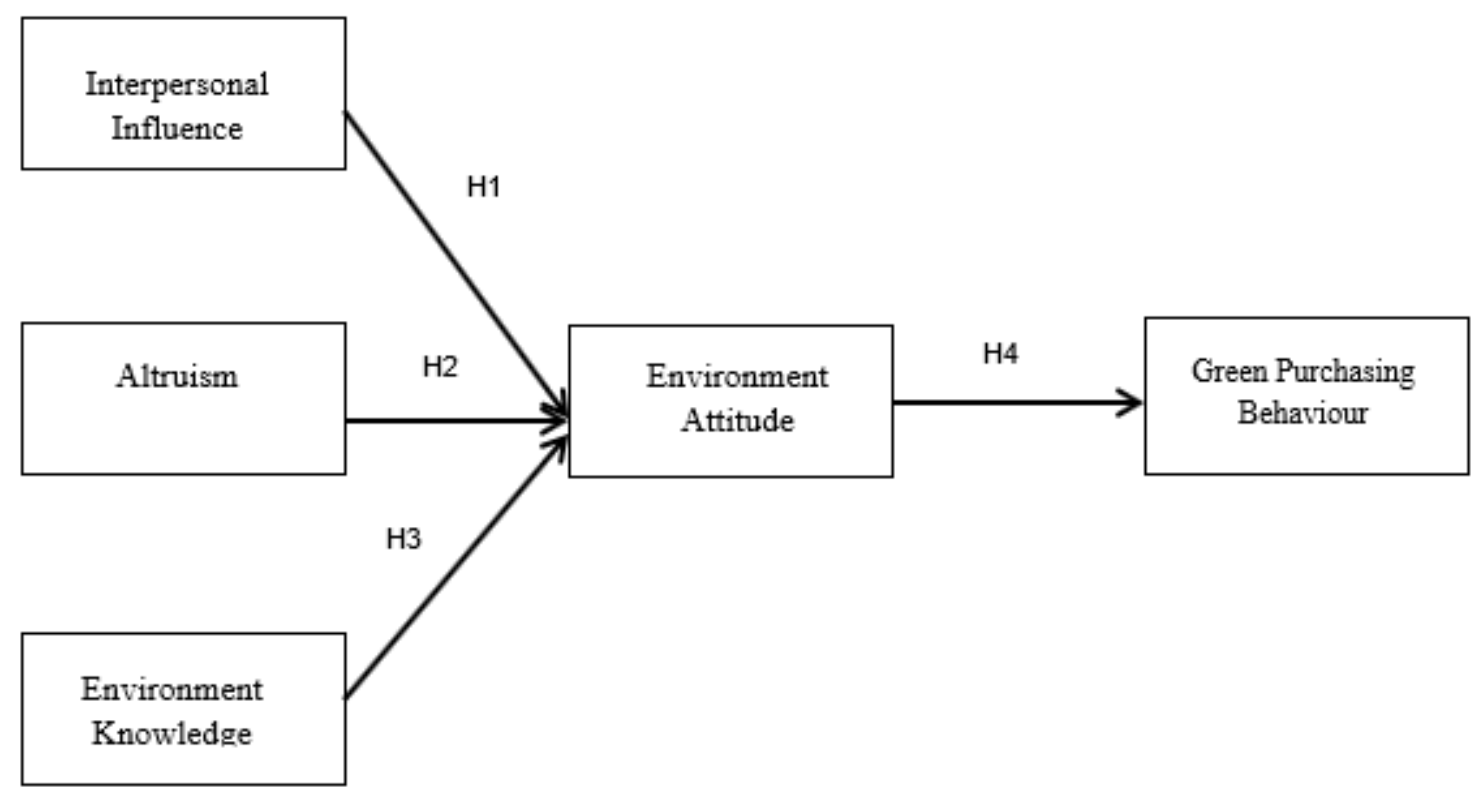

Gambar 1. Model Penelitian

Sumber: (Uddin \& Khan, 2018)

\section{METODOLOGI PENELITIAN}

\subsection{Metodologi}

Penelitian ini menggunakan metode penelitian deduktif yang mana biasanya dilakukan pada penelitian dengan pendekatan kuantitatif untuk menjelaskan hubungan keterkaitan antara interpersonal influence, altruism, dan environmental knowledge terhadap green purchasing behaviour yang dimediasi oleh environmental attitude. Dalam penelitian ini terdapat 5 variabel yang akan di ukur, yaitu interpersonal influence, altruism, environmental knowledge, environmental attitude dan green purchasing behaviour. Dimana interpersonal influence, altruism, environmental knowledge sebagai variabel independen yang akan mempengaruhi green purchasing behaviour sebagai variabel dependen dan environmental attitude sebagai variabel mediasi. Pada penelitian ini, teknik pengambilan sampel akan menggunakan 
nonprobablity sampling dengan teknik pengambilan sampel purposive sampling yang merupakan strategi di mana orang atau peristiwa tertentu dipilih secara sengaja untuk memberikan informasi penting yang tidak dapat diperoleh dari pilihan lain (Maxwell, 2016). Jumlah sampel yang ditentukan berdasarkan pernyataan Raykov \& Marcoulides (2012), yang dimana ukuran sampel yang baik dihitung berdasarkan jumlah indikator dikali 10, sehingga sampel yang dibutuhkan adalah 210 karena terdapat 21 indikator dikali dengan 10. Skala yang digunakan pada penelitian ini adalah skala interval. Skala interval yang digunakan dalam penelitian ini adalah skala Likert 5 poin dengan menguji seberapa tidak setuju dan seberapa seberapa setujunya responden terhadap pernyataan yang diberikan. Peneliti menyebarkan kuesioner menggunakan teknik Electronic and online questionnaires dengan menggunakan google form dengan harapan peneliti dapat menjangkau responden yang luas dengan cepat dan waktu yang singkat.

\subsection{Profil Responden}

Profil responden yang ada dalam penelitian ini berjumlah 210 orang dan disajikan pada tabel berikut:

Tabel 1. Profil Responden

\begin{tabular}{|c|c|c|c|}
\hline \multicolumn{2}{|c|}{ Kategori } & Jumlah Responden & Persentase \\
\hline \multirow{2}{*}{ Jenis Kelamin } & Pria & 47 & $22.4 \%$ \\
\hline & Wanita & 163 & $77.6 \%$ \\
\hline \multicolumn{2}{|c|}{ Kategori } & Jumlah Responden & Persentase \\
\hline \multirow{2}{*}{ Usia } & $<18$ tahun & 32 & $15.24 \%$ \\
\hline & 18-24 tahun & 156 & $74.29 \%$ \\
\hline \multirow{5}{*}{ Usia } & 25-34 tahun & 20 & $9.52 \%$ \\
\hline & 35-44 tahun & 2 & $0.95 \%$ \\
\hline & $45-54$ tahun & 0 & 0 \\
\hline & 55-64 tahun & 0 & 0 \\
\hline & $>64$ tahun & 0 & $\overline{0}$ \\
\hline \multirow{3}{*}{ Pendidikan } & SMA atau Sederajat & 110 & $52.4 \%$ \\
\hline & $\mathrm{S} 1$ & 91 & $43.3 \%$ \\
\hline & S2 & 9 & $4.3 \%$ \\
\hline \multirow{5}{*}{ Domisili } & Jakarta & 56 & $26.7 \%$ \\
\hline & Tangerang & 46 & $21.9 \%$ \\
\hline & Depok & 17 & $8.1 \%$ \\
\hline & Bekasi & 23 & $10.9 \%$ \\
\hline & Bogor & 68 & $32.4 \%$ \\
\hline \multirow{5}{*}{ Pendapatan } & $<$ Rp. 1.000 .000 & 74 & $35.2 \%$ \\
\hline & $\begin{array}{c}\text { Rp. } 1.100 .000-\text { Rp. } \\
3.000 .000\end{array}$ & 60 & $28.6 \%$ \\
\hline & $\begin{array}{c}\text { Rp. } 3.100 .000-\mathrm{Rp} . \\
5.000 .000\end{array}$ & 37 & $17.6 \%$ \\
\hline & $\begin{array}{c}\text { Rp. } 5.100 .000-\mathrm{Rp} . \\
10.000 .000\end{array}$ & 23 & $11 \%$ \\
\hline & $>$ Rp. 10.000 .000 & 16 & $7.6 \%$ \\
\hline
\end{tabular}




\subsection{Uji Reliabilitas Aktual}

Uji reliabilitas bertujan untuk mengukur tingkat konsistensi indikator terhadap suatu variabel dan juga digunakan dalam mengukur tingkat konsistensi responden saat menjawab pertanyaan pada kuesioner agar indikator tersebut dapat dianggap reliable (Edward G. Carmines \& Zeller, 1979). Pada penelitian ini, uji reliabilitas yang digunakan adalah dengan menggunakan composite reliability dengan alasan pendekatan dengan asumsi parameter lebih akurat. Dimana composite reliability harus lebih tinggi dari 0.70 agar dapat dinyatakan reliable (Jr et al., 2018).

Tabel 2. Hasil Uji Reliabilitas berdasarkan Composite Reliability

\begin{tabular}{|c|c|c|}
\hline & $\begin{array}{c}\text { Composite } \\
\text { Reliability }\end{array}$ & $\begin{array}{c}\text { Keputusan }( \\
\mathbf{> 0 , 7 0})\end{array}$ \\
\hline ujn & 0,820 & Reliabel \\
\hline EA & 0,881 & Reliabel \\
\hline EK & 0,867 & Reliabel \\
\hline GPB & 0,889 & Reliabel \\
\hline IF & 0,906 & Reliabel \\
\hline
\end{tabular}

Sumber: Hasil pengolahan data (2020)

Note: AL : Altruism

EA : Environment Attitude

EK : Environment Knowledge

GPB : Green Purchasing Behaviour

IF : Interpersonal Influence

Cronbach's alpha reliability menggambarkan keandalan jumlah (atau rata-rata) pengukuran di mana pengukuran tersebut dapat mewakili ukuran, kejadian, bentuk alternatif, atau item kuesioner. Berdasarkan Cronbach's Alpha, dasar pengambilan keputusan adalah sebagai berikut: Nilai diatas 0.70 umumnya menunjukkan reabilitas yang baik (Jr et al., 2018).

Tabel 3. Hasil Uji Reliabilitas berdasarkan Cronbach's alpha reliability

\begin{tabular}{|c|c|c|}
\hline & Cronbach's Alpha & $\mathbf{> 0 . 6 0}$ \\
\hline AL & 0,679 & Reliabel \\
\hline EA & 0,796 & Reliabel \\
\hline EK & 0,796 & Reliabel \\
\hline GPB & 0,833 & Reliabel \\
\hline IF & 0,881 & Reliabel \\
\hline
\end{tabular}

Sumber: Hasil pengolahan data (2020)

Note: AL : Altruism

EA : Environment Attitude

EK : Environment Knowledge

GPB : Green Purchasing Behaviour

IF : Interpersonal Influence 


\subsection{Uji Validitas Aktual}

Uji validitas ditujukan untuk melihat sejauh mana ketepatan instrumen dalam mengukur suatu variabel yang ingin diukur (Sekaran \& Bougie, 2016). Dalam penelitian ini, uji validitas yang digunakan adalah validitas konvergen dan validitas diskriminan. Validitas konvergen dapat dievaluasi melalui dua tahap yaitu melalui nilai Average Variance Extract $(A V E)$ dan nilai factor loading. Indikator dianggap valid apabila nilai $A V E$ lebih besar dari 0.5 (Jr et al., 2018) serta nilai factor loading lebih besar dari 0.7 (Ghozali, 2017).

Tabel 4. Uji Validitas Konvergen Aktual Berdasarkan Factor Loading

\begin{tabular}{|c|c|c|c|c|c|}
\hline & $A L$ & EA & EK & GPB & IF \\
\hline AL1 & 0,810 & & & & \\
\hline AL2 & 0,733 & & & & \\
\hline AL3 & 0,786 & & & & \\
\hline EA1 & & 0,884 & & & \\
\hline EA2 & & 0,823 & & & \\
\hline EA3 & & 0,822 & & & \\
\hline EK2 & & & 0,772 & & \\
\hline EK3 & & & 0,855 & & \\
\hline EK4 & & & 0,815 & & \\
\hline EK5 & & & 0,705 & & \\
\hline GPB1 & & & & 0,879 & \\
\hline GPB2 & & & & 0,797 & \\
\hline GPB3 & & & & 0,870 & \\
\hline GPB4 & & & & 0,714 & \\
\hline IF1 & & & & & 0,833 \\
\hline IF2 & & & & & 0,856 \\
\hline IF3 & & & & & 0,705 \\
\hline IF4 & & & & & 0,808 \\
\hline IF5 & & & & & 0,848 \\
\hline
\end{tabular}

Sumber: Hasil pengolahan data (2020)

Note: AL : Altruism

EA : Environment Attitude

EK : Environment Knowledge

GPB : Green Purchasing Behaviour

IF : Interpersonal Influence 
Tabel 5. Hasil Uji Validitas Konvergen Aktual - AVE

\begin{tabular}{|c|c|c|}
\hline & Average Variance Extracted (AVE) & $\begin{array}{c}\text { Keputusan ( } \\
\mathbf{> 0 , 5 0 )}\end{array}$ \\
\hline AL & 0,603 & Valid \\
\hline EA & 0,711 & Valid \\
\hline EK & 0,622 & Valid \\
\hline GPB & 0,668 & Valid \\
\hline IF & 0,659 & Valid \\
\hline
\end{tabular}

Sumber: Hasil pengolahan data (2020)

Note: AL : Altruism

EA : Environment Attitude

EK : Environment Knowledge

GPB : Green Purchasing Behaviour

IF : Interpersonal Influence

Kriteria selanjutnya untuk menguji validitas diskriminan adalah dengan melihat nilai Heterotrait-Monotrait (HTMT) yang harus lebih rendah dari 0.8. Kriteria selanjutnya dalam uji validitas diskriminan adalah dengan melihat nilai Heterotrait-Monotrait Ratio (HTMT) dengan batas nilai HTMT maksimum adalah 0.85 (Clark \& Watson, 1995; Kline, 2015).

Tabel 6. Hasil Uji Validitas Diskriminan Aktual - Heterotrait-Monotrait Ratio (HTMT)

\begin{tabular}{|l|r|r|r|l|l|}
\hline & \multicolumn{1}{|l|}{ AL } & EA & EK & GPB & IF \\
\hline AL & & & & & \\
\hline EA & 0,454 & & & & \\
\hline EK & 0,647 & 0,234 & & & \\
\hline GPB & 0,112 & 0,437 & 0,189 & & \\
\hline IF & 0,182 & 0,157 & 0,400 & 0,115 & \\
\hline
\end{tabular}

Sumber: Hasil pengolahan data (2020)

Note: AL : Altruism

EA : Environment Attitude

EK : Environment Knowledge

GPB : Green Purchasing Behaviour

IF : Interpersonal Influence

Kriteria selanjutnya adalah dengan menilai hasil nilai indikator Outer VIF $<3,3$ maka dapat disimpulkan bahwa bahwa seluruh indikator bebas dari bias. 
Tabel 7. Collinearity Statistic (VIF) Outer VIF Values $<3,3$

\begin{tabular}{|c|c|}
\hline & VIF \\
\hline AL1 & 1,242 \\
\hline $\mathrm{AL2}$ & 1,377 \\
\hline AL3 & 1,390 \\
\hline EA1 & 2,026 \\
\hline EA2 & 1,649 \\
\hline EA3 & 1,631 \\
\hline EK2 & 1,791 \\
\hline EK3 & 2,303 \\
\hline EK4 & 1,955 \\
\hline EK5 & 1,237 \\
\hline GPB1 & 2,179 \\
\hline GPB2 & 1,947 \\
\hline GPB3 & 2,348 \\
\hline GPB4 & 1,458 \\
\hline IF1 & 2,286 \\
\hline IF2 & 2,477 \\
\hline IF3 & 2,097 \\
\hline IF4 & 2,107 \\
\hline IF5 & 1,978 \\
\hline
\end{tabular}

Sumber: Hasil pengolahan data (2020)

Pada tahap uji nilai inner VIF tidak ada bias pada model penelitian karena seluruh indikator menunjukkan nilai $<3,3$ yang akan dipaparkan oleh tabel berikut:

Tabel 8. Collinearity Statistic (VIF) Inner VIF Values $<3,3$

\begin{tabular}{|l|l|r|l|l|l|}
\hline & AL & EA & EK & GPB & IF \\
\hline AL & & $\mathbf{1 , 3 1 1}$ & & & \\
\hline EA & & & & 1,000 & \\
\hline EK & & 1,430 & & & \\
\hline GPB & & & & & \\
\hline IF & & 1,110 & & & \\
\hline
\end{tabular}

Sumber: Hasil pengolahan data (2020) 


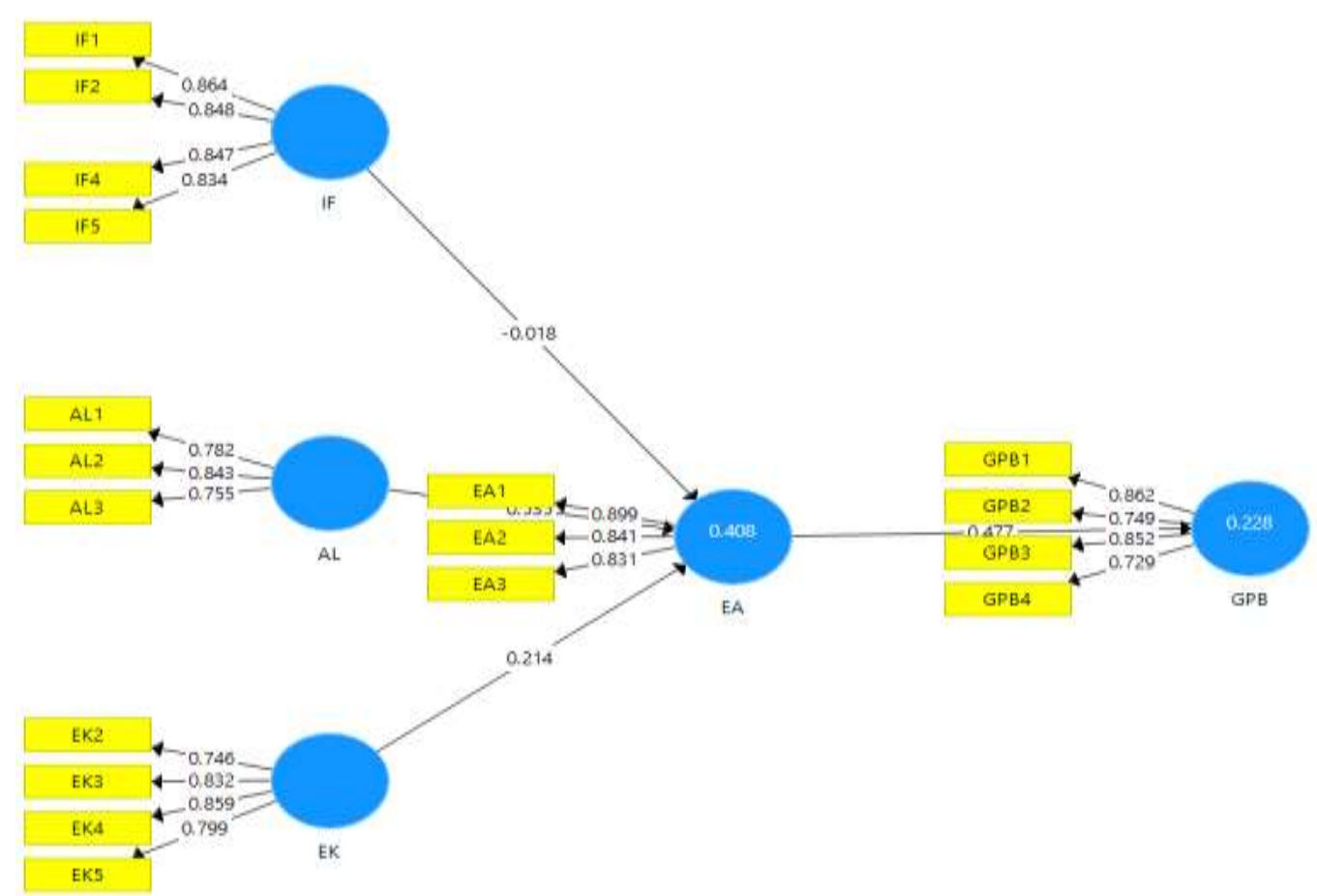

Gambar 2. Model Structural Berdasarkan SmartPLS

Sumber: Hasil Analisis Data Dengan Menggunakan SmartPLS (2020)

Koefisien determinasi atau $\mathrm{R}^{2}$ dilakukan untuk mengukur besarnya pengaruh variabel independen terhadap variabel dependen. Ketika nilai yang dihasilkan $\mathrm{R}^{2}$ semakin tinggi atau mendekati 1, itu berarti kemampuan variabel independen dalam menjelaskan variabel dependen menajdi semakin besar. Berikut adalah nilai dari koefisien determinasi $\left(\mathrm{R}^{2}\right)$. Nilai $\mathrm{Q}^{2}$ digunakan sebagai sampel konstruk eksogen yang relevan secara prediktif terhadap konstruk endogen dengan angka $>0$. Nilai aturan praktis $\mathrm{Q}^{2}$ adalah 0,02 (kecil), 0,15 (sedang), dan 0,35 (tinggi) terhadap konstruk endogen (Hair, J. F., Hult, G. T. M., Ringle, C. M., \& Sarstedt, 2013).

Tabel 9. Nilai R Square $\left(R^{2}\right)$ dan $Q$ Square $\left(Q^{2}\right)$

\begin{tabular}{|c|c|c|}
\hline & $\mathbf{R}^{2}$ & $\mathbf{Q}^{2}$ \\
\hline EA & 0,131 & 0,118 \\
\hline GPB & 0,130 & 0,126 \\
\hline
\end{tabular}

Sumber: Hasil pengolahan data (2020)

Note: EA : Environment Attitude

GPB : Green Purchasing Behaviour

\section{HASIL PENELITIAN DAN DISKUSI}

Berdasarkan hasil analisa dan pembahasan sebelumnya mengenai analisis pengaruh interpersonal influence, altruism, dan environment knowledge terhadap green purchasing behaviour konsumen The Body Shop yang dimediasi oleh environment attitude, maka dapat disimpulkan bahwa berdasarkan hasil analisis penelitian, interpersonal influence memiliki 
pengaruh yang positif senilai 1.294 dan tidak signifikan senilai 0.196 terhadap environment attitude konsumen The Body Shop. Maka dari itu, dapat disimpulkan bahwa interpersonal influence $12,9 \%$ berpengaruh terhadap environment attitude. Berdasarkan hasil analisis penelitian, altruism memiliki pengaruh yang positif senilai 3.766 dan signifikan terhadap environment attitude konsumen The Body Shop. Maka dari itu, dapat disimpulkan bahwa altruism 37,6\% berpengaruh terhadap environment attitude. Berdasarkan hasil analisis penelitian, environment knowledge tidak berpengaruh secara positif senilai 0.098 dan tidak signifikan senilai 0.922 terhadap environment attitude konsumen The Body Shop. Maka dari itu, dapat disimpulkan bahwa environment knowledge $9.8 \%$ tidak berpengaruh terhadap environment attitude. Berdasarkan hasil analisis penelitian, environment attitude memiliki pengaruh yang positif senilai 6.656 dan signifikan terhadap green purchasing behaviour konsumen The Body Shop. Maka dari itu, dapat disimpulkan bahwa environment attitude $66.5 \%$ berpengaruh terhadap green purchasing behavior. Hasil uji hipotesis dirangkum dalam tabel berikut:

Tabel 10. Hasil Uji Hipotesis

\begin{tabular}{|l|l|l|l|l|l|l|}
\hline Hipotesis & $\begin{array}{l}\text { Original } \\
\text { Sample (O) }\end{array}$ & $\begin{array}{l}\text { Sample } \\
\text { Mean } \\
(\mathbf{M})\end{array}$ & $\begin{array}{l}\text { Standard } \\
\text { Deviation } \\
\text { (STDEV) }\end{array}$ & $\begin{array}{l}\text { T Statistics } \\
(\mid \mathbf{O} / \text { STDEV })\end{array}$ & P Values & Hasil uji \\
\hline AL -> EA & 0.333 & 0.324 & 0.089 & 3.766 & $\mathbf{0 . 0 0 0}$ & Didukung \\
\hline EA -> GPB & 0.361 & 0.369 & 0.054 & 6.656 & $\mathbf{0 . 0 0 0}$ & Didukung \\
\hline EK -> EA & -0.008 & 0.013 & 0.082 & 0.098 & $\mathbf{0 . 9 2 2}$ & Tidak Didukung \\
\hline IF -> EA & 0.114 & 0.124 & 0.088 & 1.294 & $\mathbf{0 . 1 9 6}$ & Tidak Didukung \\
\hline
\end{tabular}

\section{KESIMPULAN}

\subsection{Kesimpulan}

Pada penelitian ini terdapat perbedaan dari penelitian Uddin \& Khan (2018) karena pada penelitian ini peneliti mengembangkan objek yang lebih spesifik pada industri kosmetik yaitu The Body Shop. Pada variabel environment knowledge ditemukan bahwa sebesar 9,8\% variable tersebut tidak berpengaruh pada green purchasing behavior konsumen The Body Shop. Variabel ini tidak berpengaruh pada industri kosmetik dapat terjadi dikarenakan kosumen lebih memilih untuk membeli produk dengan merek lain atau harga produk yang lebih murah sehingga kosumen masih memiliki pengetahuan yang rendah akan dampak pembelian mereka terhadap lingkungan. Hal ini didukung oleh hasil dari penelitian Rakhmawati (2019) yang mana dari penelitian tersebut ditemukan bahwa konsumen lebih cenderung untuk melihat merek suatu produk kosmetik daripada produk ramah lingkungan itu sendiri. Pada penelitian ini juga environment knowledge tidak berpengaruh secara positif senilai 0.098 dan tidak signifikan senilai 0.922 terhadap environment attitude konsumen The Body Shop, peran dari pemasar harus ditingkatkan untuk dapat memberikan informasi yang dapat menambah wawasan dari konsumen The Body Shop.

\subsection{Implikasi/Batasan dan Saran untuk Penelitian Selanjutnya}

Implikasi manajerial yang dapat diberikan pada penelitian ini adalah pentingnya interpersonal influence, altruism, environment knowledge konsumen membentuk sikap konsumen terhadap lingkungan dan menyebabkan perilaku pembelian produk ramah lingkungan. Konsumen The Body Shop menunjukkan pemahaman altruistik welas asih tentang perilaku pembelian ramah 
lingkungan yang cukup tinggi, namun untuk menerapkan pengetahuan akan lingkungan masih menjadi masalah untuk konsumen The Body Shop. Melalui penelitian ini, diharapkan dapat menambahkan informasi bagi praktisi pemasaran, manajer dan pembuat kebijakan tentang prediktor utama konsumerisme hijau di antara konsumen The Body Shop. Pemasar harus memperhatikan perilaku pembelian konsumen terhadap produk ramah lingkungan. Karena dengan pemahaman ini diharapkan dapat membantu pemasar dalam memasarkan produk The Body Shop kedepannya. Dalam penelitian ini juga ditemukan bahwa sikap lingkungan berpengaruh positif dan signifikan terhadap perilaku pembelian produk ramah lingkungan. Hal ini dipengaruhi oleh pengaruh interpersonal, nilai altruistik dan juga pengetahuan tentang lingkungan. Pengetahuan akan lingkungan kosumen The Body Shop yang masih rendah dapat dijadikan sebagai referensi bagi pemasar agar aktif untuk menyebarkan informasi dan sosialisasi tentang masalah yang terjadi pada lingkungan sehingga dapat mendorong konsumen untuk membeli produk ramah lingkungan. Pemasar juga dapat bekerja sama dengan para influencer dalam mempengaruhi masyarakat untuk membantu mendorong masyarakat membeli produk ramah lingkungan. Karena saat ini, banyak perusahaan telah menggunakan influencer dalam memasarkan produk mereka ataupun untuk membantu menjalankan kampanye-kampanye suatu perusahaan. Konsumen juga akan lebih mudah untuk mengerti dan lebih tertarik karena masayarakat menganggap influencer sama seperti mereka yaitu sebagai konsumen. Perusahaan juga dapat menambah produk-produk baru untuk menarik konsumen baru. Penelitian ini hanya dilakukan pada 5 wilayah yaitu Jakarta, Tangerang, Depok, Bekasi dan Bogor. Agar penelitian selanjutnya dapat memperluas daerah penelitian ke kota-kota lainnya selain Jakarta, Tangerang, Depok, Bekasi dan Bogor. Penelitian selanjutnya dapat meneliti subjek yang lebih banyak lagi karena memungkinkan untuk mendapatkan hasil penelitian yang berbeda dengan jumlah responden yang lebih banyak. Karena pada penelitian ini hanya diteliti kepada 210 responden. Penelitian selanjutnya dapat menambahkan variabel lain untuk diteliti selain variabel yang dibahas pada penelitian ini. Seperti tujuan kosumen (consumer intention) dalam membeli produk ramah lingkungan atau psikologis konsumen dalam niat pembelian produk ramah lingkungan dan juga kesediaan konsumen untuk membayar produk ramah lingkungan (willingness to pay). Penelitian selanjutnya dapat menggunakan objek penelitian selain perusahaan yang bergerak di bidang kesehatan dan kecantikan. Peneliti berharap agar keterbatasan pada penelitian ini dapat diatasi lebih baik oleh penelitian selanjutnya sehingga keterbatasan penelitian ini dapat diselesaikan.

\section{REFERENSI}

Ajzen, I. (1985). From Intentions to Actions: A Theory of Planned Behavior. In Action Control. https://doi.org/10.1007/978-3-642-69746-3_2

Albayrak, T., Moutinho, L., \& Herstein, R. (2011). The influence of skepticism on green purchase behavior Tahir Albayrak, PhD Akdeniz University School of Tourism and Hotel Management Campus University of Glasgow Foundation Chair of Marketing Ram Herstein PhD Ruppin Academic Center Marketing Department. November 2014.

Arseculeratne, D., \& Yazdanifard, R. (2013). How Green Marketing Can Create a Sustainable Competitive Advantage for a Business. International Business Research. https://doi.org/10.5539/ibr.v7n1p130

Chang, C. (2011). Feeling ambivalent about going green: Implications for green advertising processing. Journal of Advertising, 40(4), 19-31. https://doi.org/10.2753/JOA00913367400402 
Clark, L. A., \& Watson, D. (1995). Constructing Validity: Basic Issues in Objective Scale Development. Psychological Assessment. https://doi.org/10.1037/1040-3590.7.3.309

Edward G. Carmines, \& Zeller, R. A. (1979). Reliability and validity assessment.pdf. In series: Quantitative Applications in the social sciences.

Ghozali, I. (2017). Model Persamaan Struktural. Konsep dan Aplikasi Dengan Program AMOS 24.0. Update Bayesian SEM. In Model Persamaan Struktural. Konsep dan Aplikasi Dengan Program AMOS 24. Update Bayesian SEM.

Gilg, A., Barr, S., \& Ford, N. (2005). Green consumption or sustainable lifestyles? Identifying the sustainable consumer. Futures, 37(6), 481-504. https://doi.org/10.1016/j.futures.2004.10.016

Gohary, M., Hussin, A. R. C., \& Abdollahzadehgan, A. (2013). Human factors' impact leveraging cloud based applications adoption. Journal of Information Systems Research and Innovation.

Hair, J. F., Hult, G. T. M., Ringle, C. M., \& Sarstedt, M. (2013). A Primer on Partial Least Squares Structural Equation Modeling (PLS-SEM). Thousand Oaks. In Sage.

International, E. (2020). Skin Care in Indonesia. Https://Www.Euromonitor.Com/Skin-Carein-Indonesia/Report.

Jennifer Gubitosa, Vito Rizzi, Paola Fini, P. C. (2019). Inonotus obliquus extract as an inhibitor of $\alpha$-MSH-induced melanogenesis in B16F10 mouse melanoma cells. Cosmetics, 6(1), 116. https://doi.org/10.3390/cosmetics6010013

Jermier, J. M., \& Prakash, A. (2002). Greening the Firm: The Politics of Corporate Environmentalism. Administrative Science Quarterly. https://doi.org/10.2307/3094854

Joshi, Y., \& Rahman, Z. (2015). Factors Affecting Green Purchase Behaviour and Future Research Directions. International Strategic Management Review. https://doi.org/10.1016/j.ism.2015.04.001

Jr, J. F. H., Black, W. C., Babin, B. J., Anderson, R. E., Black, W. C., \& Anderson, R. E. (2018). Multivariate Data Analysis. https://doi.org/10.1002/9781119409137.ch4

Kline, R. B. (2015). Principles and practice of structural equation modelling (4th ed.). Methodology in the Social Sciences.

Kumar, V., Rahman, Z., Kazmi, A. A., \& Goyal, P. (2012). Evolution of Sustainability as Marketing Strategy: Beginning of New Era. Procedia - Social and Behavioral Sciences, 37, 482-489. https://doi.org/10.1016/j.sbspro.2012.03.313

Lee, K. (2011). The green purchase behavior of hong kong young consumers: The role of peer influence, local environmental involvement, and concrete environmental knowledge. Journal of International Consumer Marketing, 23(1), 21-44. https://doi.org/10.1080/08961530.2011.524575

Mathieson, K. (1991). Predicting user intentions: Comparing the technology acceptance model with the theory of planned behavior. Information Systems Research. https://doi.org/10.1287/isre.2.3.173

Maxwell, J. A. (2016). Qualitative study-marketing-mfi. June.

Mitchener, C. P., \& Jackson, W. M. (2012). Learning from Action Research About Science Teacher Preparation. Journal of Science Teacher Education. https://doi.org/10.1007/s10972-011-9261-0

Pam, N. (2013). Psychology Dictionary. PsychologyDictionary.Org. 
Polonsky, M. J. (2017). Green marketing. In Sustainable Solutions: Developing Products and Services for the Future. https://doi.org/10.4324/9781351282482-16

Rakhmawati, N. L. (2019). Pembelian Produk the Body Shop Di Kota Yogyakarta.

Raykov, T., \& Marcoulides, G. A. (2012). A First Course in Structural Equation Modeling. In A First Course in Structural Equation Modeling. https://doi.org/10.4324/9780203930687

Sekaran, U., \& Bougie, R. (2016). Research Method for Business Textbook: A Skill Building Approach. In John Wiley \& Sons Ltd.

Spencer, N. (2018). L'Oréal confirm Indonesia is its fastest growing mass market. Https:/Www.Cosmeticsdesign-Asia.Com/Article/2018/02/06/L-Oreal-ConfirmsIndonesia-Is-Its-Fastest-Growing-Mass-Market.

Stern, N. Z., \& Ander, W. N. (2012). Greentailing and Other Revolutions in Retail. In Greentailing and Other Revolutions in Retail. https://doi.org/10.1002/9781119197393

Taherdoost, H. (2018). Sampling Methods in Research Methodology; How to Choose a Sampling Technique for Research. SSRN Electronic Journal, September. https://doi.org/10.2139/ssrn.3205035

Teng, Y. M., Wu, K. S., \& Liu, H. H. (2015). Integrating Altruism and the Theory of Planned Behavior to Predict Patronage Intention of a Green Hotel. Journal of Hospitality and Tourism Research, 39(3), 299-315. https://doi.org/10.1177/1096348012471383

Uddin, S. M. F., \& Khan, M. N. (2018). Young Consumer's Green Purchasing Behavior: Opportunities for Green Marketing. Journal of Global Marketing. https://doi.org/10.1080/08911762.2017.1407982

Wibowo, A. (2020). Indonesian Skincare Product Insights: Paying for The "Glow." Https://Janio.Asia/Sea/Indonesia/Indonesia-Skincare-Ecommerce-Trends/. 